\title{
Influence of Employee Development, Motivation and Leadership on the Performance of Civil Servants, Job Satisfaction as Moderator Variable: A Case of the Jambi Regional Police
}

\author{
Mukhtarmizi, Amri Amir", Edward Edward, Ade Octavia \\ Doctoral Program in Economics, Universitas Jambi, Indonesia
}

*Corresponding Author

Amri Amir

Article History

Received: 02.04.2020

Accepted: 10.04 .2020

Published: 14.04.2020

\begin{abstract}
This study aims to analyze the influence of development, motivation and leadership on the performance of civil servants with job satisfaction as the moderator variable especially in the Jambi Regional Police. The analysis model is the the Structural Equation Modeling Partial Least Square (SEM - PLS). The results showed that, there is no influence of development on job satisfaction. Motivation has a positive effect on job satisfaction. Leadership has a positive significant effect on job satisfaction. Job satisfaction has an influence on employee performance. Employee development affects the performance. Motivation moderated by job satisfaction has insignificant impact to performance. Furthermore, job satisfaction can moderate the influence of leadership on the performance.
\end{abstract}

Keywords: Civil servants, Job satisfaction, Leadership, Motivation, Performance.

\section{INTRODUCTION}

Development provides benefits to employees, for instance, better positions and careers. It increases organizational efficiency as well. Skilled employees provide better performance at work. Employee development includes training, work experience and job rotation. Therefore only job experience as the independent variable has a significant and positive impact on the dependent variable (employee performance). Meanwhile the other independent variables are found to be insignificant drivers in influencing employee performance [1]. The issue or problem relating to employee development today is there are many employees of an institution/organization who do not want to improve their work performance through education, work experience, and training, and it is resulting on the bad performance of employee. There are many employees whose education attainment is low (high school and diploma) and which have no interest in continuing their study to the higher education level [2].

Employee development is much needed by an organization due to: 1) the existence of technologies used by employees at work in the form of new applications/software; 2) the lack of employees' skills in using technology-based work tools. Organization's program therefore cannot be carried out optimally; 3) so that employees can work in total, it is necessary to hold employee education and training regularly; 4) the intense competition in improving services and results in various organizations [3].

It can be concluded that employee development is an activity to improve employee performance through education and training carried out by an institution or organization for the employees. Development of civil servants is going through several processes: formal education, work experience and training.

According to Akhmal [4] there is a relationship between employee development and job satisfaction, where employee development has a positive influence on job satisfaction but its coefficient of determination is $29.4 \%$. The results of his study indicate that work experience and training does not always increase job satisfaction. Future research needs to be carried out on other variables that drive satisfaction of the employees.

Copyright @ 2020: This is an open-access article distributed under the terms of the Creative Commons Attribution license which permits unrestricted use, distribution, and reproduction in any medium for non commercial use (NonCommercial, or CC-BY-NC) provided the original author and source are credited. 
Motivation encourages individuals to achieve their goals and organizational goals through every challenge and obstacle in their workplace; think of it as an opportunity to move forward in their own direction. The need for achievement always results in a desire to give extra efforts to do something better and a desire for success. Managers have to motivate employees to do and finish something by themselves without getting asked to do so. Extrinsic motivation, on the other hand, is a result driven by external rewards such as salary, material, asset, prestige, and positive evaluations from others [5]. The problem related to this motivation is that the employees do not have a motivation to work even despite the reward given by the institution or organization.

Motivation has a good relationship with various activities in an institution both the government and other organizations such as: 1) motivation is closely related to the work environment, infrastructure, and implementation of organizational management, 2) motivation has a good relationship with employee, such as management, skills, knowledge, education, training and work experience, encouragement and work results achieved [6]. In other words, motivation is a form of encouragement given by one person to another person to carry out a work so as to obtain excellent results.

There are many experts discussing the theories of motivation including: the Content theory, the Taylor's Motivation theory and the Maslow's Hierarchy of Need theory, the ERG (Existence, Relatedness and Growth) theory, the Two Factor theory, the McClelland's Achievement Motivation theory and the Process theory [7].

Juniari [8] stated that there is a relationship between motivation and job satisfaction, where motivation positively influences job satisfaction. The results found that when an employee is given rewards in the form of salary, performance allowances and meal allowances, the job satisfaction of the employee increases. This satisfaction is felt when the rewards the employee received fulfill their needs.

Leadership is a method practiced by a leader to improve the performance of his/her employees in carrying out the vision and mission of the institution and organization. This is one of the leaders' efforts to improve the quality of management in an organization which can communicate well with subordinates in carrying out a main task and its function. Despite the change in the position of the leader in the institution or organization, it continues to run according to existing rules. A leader is a part of an organization that can motivate subordinates to achieve common goals and objectives of the institution [9].

Leadership is considered as a decisive and important role. It has a function of management, directed at increasing human interaction in social life, also is the process of persuading people so they will achieve organizational goals. As a group leader, one must encourage members of the organization to act as well as to achieve common goals [10]. The issue related to the leadership nowadays is that there are many leaders who do not pay attention to the quality of work of their subordinates. Good leadership is depended on the style of leadership and who exercises it so that they can pay attention to the quality of work of their subordinates to achieve progress and develop in the government institution. Furthermore, development is one form of activity to eliminate the large differences in the performance among employees in accordance with the order of the institution or organization [11].

Voon [12] defines leadership as a good relationship between leaders and subordinates to work so as to achieve the common goals together. According to Umiarso [13], the functions of leadership in an organization consist of: 1) Instructive functions, 2) Consultative functions, 3) Participatory functions, 4) Delegate functions, and 5) Controlling functions. Siagian [14] described types of the leader in leadership consist of: a) Autocratic, b) Paternalistic, c) LaissezFaire, d) Democratic, and e) Charismatic.

Thoha [15] states that there are three styles in leading an organization, including autocratic leadership style, democratic leadership style, and permissive leadership style. Leadership has various variables including: a) communication methods, b) driving motivation, c) leadership ability, d) decision making, and e) positive power [16]. In conclusion, leadership is the existence of a good and harmonious relationship and polite communication exercised by a leader to his/her subordinates at work in an organization.

According to Susanto [17], leadership has a positive significant impact to job satisfaction. The results of his study found that a good communication between leaders and subordinates at work can increase job satisfaction of their subordinates. They feel appreciated by a leader who speaks politely and clearly provides direction at work.

Employee performance can be good when there is a great encouragement and support given by a leader of an institution to the subordinate at work. That subordinate thus can finish work on time, in which the leader always gives good direction, attitude and behavior in accordance with standard operating procedure in the institution or organization. Furthermore, the job satisfaction and employee development provided by the leader can improve employee performance 
in carrying out their duties [18]. The issues or problems related to the no improvement of employee performance in an institution are: 1) Many employees finish their work beyond the allotted time; 2) institutions or organizations do not give rewards to competent employees and penalties for incompetent ones at work; 3) work space is less comfortable and clean.

Timpe [19] identifies two factors that improve employee performance: (1) Internal factors. These factors come from within an individual including spiritual and physical factor, as well as, intelligence quotient and emotional quotient. (2) External factors. These factors come from outside oneself including work environment, infrastructure, rewards, total workload, et cetera.

The decline on the performance of civil servants or Pegawai Negeri Sipil (PNS) has become a current issue. Newspaper, articles and comments in internet and television highlight every day the poor performance of civil servants. They are being regarded as employees who are less innovative at work, do many official travels that only waste state budget, often come late to work and lack enthusiasm for work. These problems are present not only in one institution but also in all government offices, including the civil servants of the Jambi Regional Police.

The number of civil servants working in the Jambi Regional Police is 319 people. Male civil servants are 91 people $(29 \%)$ and female civil servants are 228 people $(71 \%)$. It means that the majority of civil servants in the Jambi Regional Police are women.

According to Mathis [20], job satisfaction is a positive emotional state resulting from evaluating one's job experience. Job satisfaction is a good behavior possessed by an employee at work in an institution or organization. In its concept, job satisfaction is defined as the level of contentment employees feel with their job. In general, an employee feels content when the work results achieved are in accordance with other's desire and institutional or organizational goals. Whenever an employee gets results at work, that person feel satisfied [21]. Rivai [22] defines job satisfaction as an evaluation of the work done by employees which can gain satisfaction in meeting their needs.

Various factors influence one's job satisfaction, including: 1) satisfaction with the type of tasks done; 2) satisfaction of rewards; 3) satisfaction with direct supervision from superiors at work; 4) satisfaction with co-workers who work in accordance with their duties and functions at work; 5) satisfaction with the promotion given by the leader based on the employee's work [7].

Job satisfaction, therefore, is a feeling of satisfaction experienced by a leader and subordinates with works carried out by individuals and team works. One's job satisfaction usually arises if his/her works are finished with high quality results and finished on time.

According to Suprapta [23] there is a correlation between job satisfaction and employee performance, where job satisfaction has a positive result. It means that job satisfaction has a significant impact on employee performance. The results of his research indicate if the employees are satisfied with their job then their performance will improve. They will likely finish their work on time with no errors.

In this context, this study aims to analyze the influence of development, motivation and leadership on the performance of civil servants with job satisfaction as the moderator variable especially in the Jambi Regional Police.

\section{METHODS}

\section{Population and Sample}

The method used in this study is through surveys. Population of this study consists of civil servants who work in the Jambi Regional Police. Total population of 319 civil servants consists of 91 men and 228 female. Samples for each gender group is based on the Slovin formula:

$$
\mathrm{n}=\frac{\mathrm{N}}{1+\mathrm{Nd}^{2}}
$$

Where:

$$
\begin{aligned}
& \mathrm{n}=\text { sample size } \\
& \mathrm{N}=\text { population size } \\
& \mathrm{d}=\text { margin of error of } 5 \%
\end{aligned}
$$

Male samples

$$
n=\frac{91}{1+91(0,5)^{2}}=74
$$


Female samples

$$
n=\frac{228}{1+228(0,05)^{2}}=145
$$

The sampling technique used in this study was random sampling method.

\section{Data Collection}

Data were obtained through questionnaire to selected respondents. In addition, in-depth interviews were also conducted to officials within the Jambi Regional Police.

\section{Model and Analysis Techniques}

To analyze the influence of development, motivation and leadership on the performance of civil servants with job satisfaction as the moderator variable in the Jambi Regional Police, the following model is used:

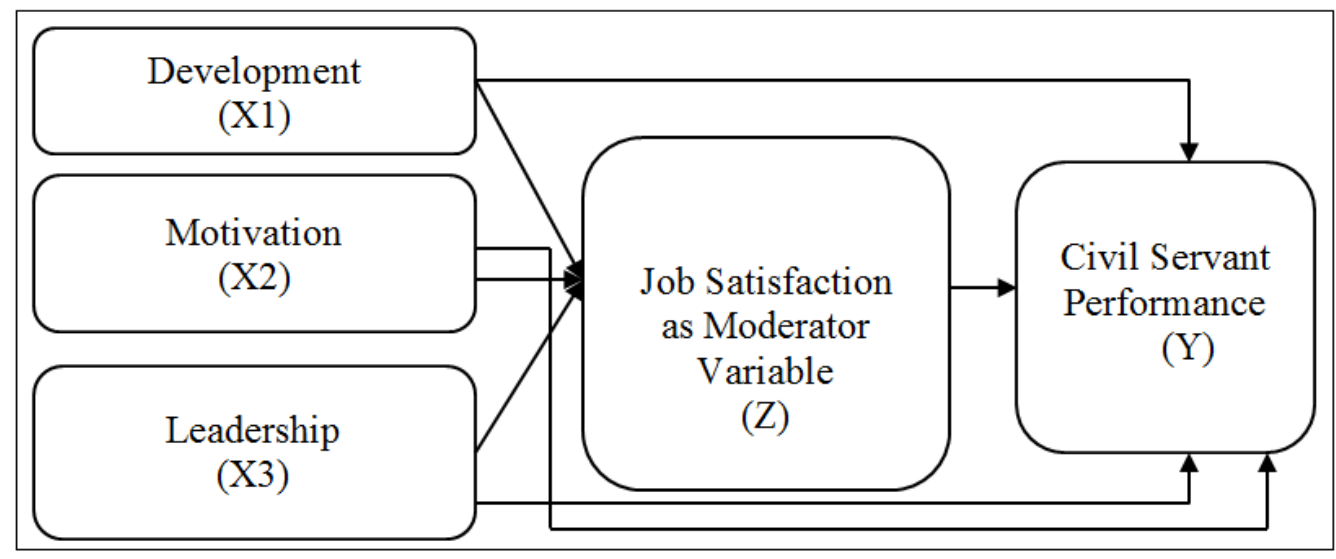

Fig-1: SEM-PLS Model

The data were analyzed using the Structural Equation Modeling Partial Least Square (SEM - PLS).

\section{Research Variables}

The variables for this study are:

Table-1: Research Variables

\begin{tabular}{|c|c|c|c|}
\hline No & Variables & Indicators & Kode \\
\hline \multirow[t]{3}{*}{1.} & \multirow[t]{3}{*}{ Development } & 1. Education & $\mathrm{X} 1.1$ \\
\hline & & 2. Work Experience & $\mathrm{X} 1.2$ \\
\hline & & 3. Training & $\mathrm{X} 1.3$ \\
\hline \multirow[t]{4}{*}{2.} & \multirow[t]{4}{*}{ Motivation } & 1. Supervision & $\mathrm{X} 2.1$ \\
\hline & & 2. Work Environment & $\mathrm{X} 2.2$ \\
\hline & & 3. Rewards & $\mathrm{X} 2.3$ \\
\hline & & 4. Attitude & $\mathrm{X} 2.4$ \\
\hline \multirow[t]{5}{*}{3} & \multirow[t]{5}{*}{ Leadership } & 1. Communication Methods & $\mathrm{X} 3.1$ \\
\hline & & 2. Driving motivation & $\mathrm{X} 3.2$ \\
\hline & & 3. Leadership Ability & $\mathrm{X} 3.3$ \\
\hline & & 4. Decision Making & X3.4 \\
\hline & & 5. Positive power & $\mathrm{X} 3.5$ \\
\hline \multirow[t]{4}{*}{4} & \multirow[t]{4}{*}{ Performance of Civil Servants } & 1. Workload & Y1 \\
\hline & & 2. Work Quality & Y2 \\
\hline & & 3. $\quad$ Attendance & Y3 \\
\hline & & 4. $\quad$ Teamwork Skills & Y4 \\
\hline \multirow[t]{5}{*}{5} & \multirow[t]{5}{*}{ Job Satisfaction } & 1. Satisfaction with Tasks & $\mathrm{Z1}$ \\
\hline & & 2. Satisfaction of Rewards & $\mathrm{Z2}$ \\
\hline & & 3. Satisfaction of the Leader's Supervision & $\mathrm{Z3}$ \\
\hline & & 4. Satisfaction with Co-workers & $\mathrm{Z4}$ \\
\hline & & 5. Promotion Opportunities & $\mathrm{Z5}$ \\
\hline
\end{tabular}




\section{RESULTS AND DisCUSSION \\ Description of Variables}

Development as the variable uses 16 indicators: 4 indicators for education, 5 indicators for work experience, and 6 indicators for training. All indicators use a 5 -point scale $(1=$ strongly disagree, $5=$ strongly agree $)$. Furthermore, the validity test was carried out for the data used. All indicators of development, education (X1.1), work experience (X1.2) and training (X1.3), are valid.

Motivation as the variable uses 18 indicators covering 4 dimensions: 3 indicators for supervision, 4 indicators for work experience, 6 indicators for rewards and 5 indicators for attitude. The results of the validity test find that supervision (X2.1) and rewards (X2.3) are valid, while work environment (X2.2) and attitude (X2.4) are invalid. These invalid indicators are thus removed.

Leadership as the variable has five indicators: communication methods, driving motivation, leadership ability, decision making and positive power. Measurement of leadership uses 32 indicators covering 5 dimensions: 9 indicators for communication methods, 7 indicators for driving motivation, 7 indicators for leadership ability, 4 indicators for decision making and 5 indicators for positive power. The results of the validity test indicate that communication methods (X3.1), leadership ability (X3.3) and positive power (X3.5) are invalid. Driving motivation (X3.2) and decision making (X3.4) are valid.

Performance of civil servants as the variable uses 20 indicators covering 4 dimensions: 4 indicators for workload, 7 indicators for work quality, 4 indicators for attendance and 5 indicators for teamwork skills. Results of the validity test show that workload (Y1) and work quality (Y2) are valid, while attendance (Y3) and teamwork skills (Y4) are invalid.

Job satisfaction as the variable uses 39 indicators covering 5 dimensions: 8 indicators for satisfaction with tasks, 6 indicators for satisfaction of rewards, 9 indicators for satisfaction of the leader's supervision, 8 indicators for satisfaction with coworkers and 8 indicators for promotion opportunities. From the results of the validity test of job satisfaction, satisfaction of rewards (Z2), satisfaction with coworkers (Z4) and promotion opportunities (Z5) are invalid. satisfaction with tasks (Z1) and satisfaction of the leader's supervision (Z3) are valid.

\section{Outer Model Testing \\ Convergent Validity}

The indicator is valid if the convergent validity value between the latent variable and the indicator is higher than 0.7. The correlation between the indicators and its construct is shown in Figure-2:

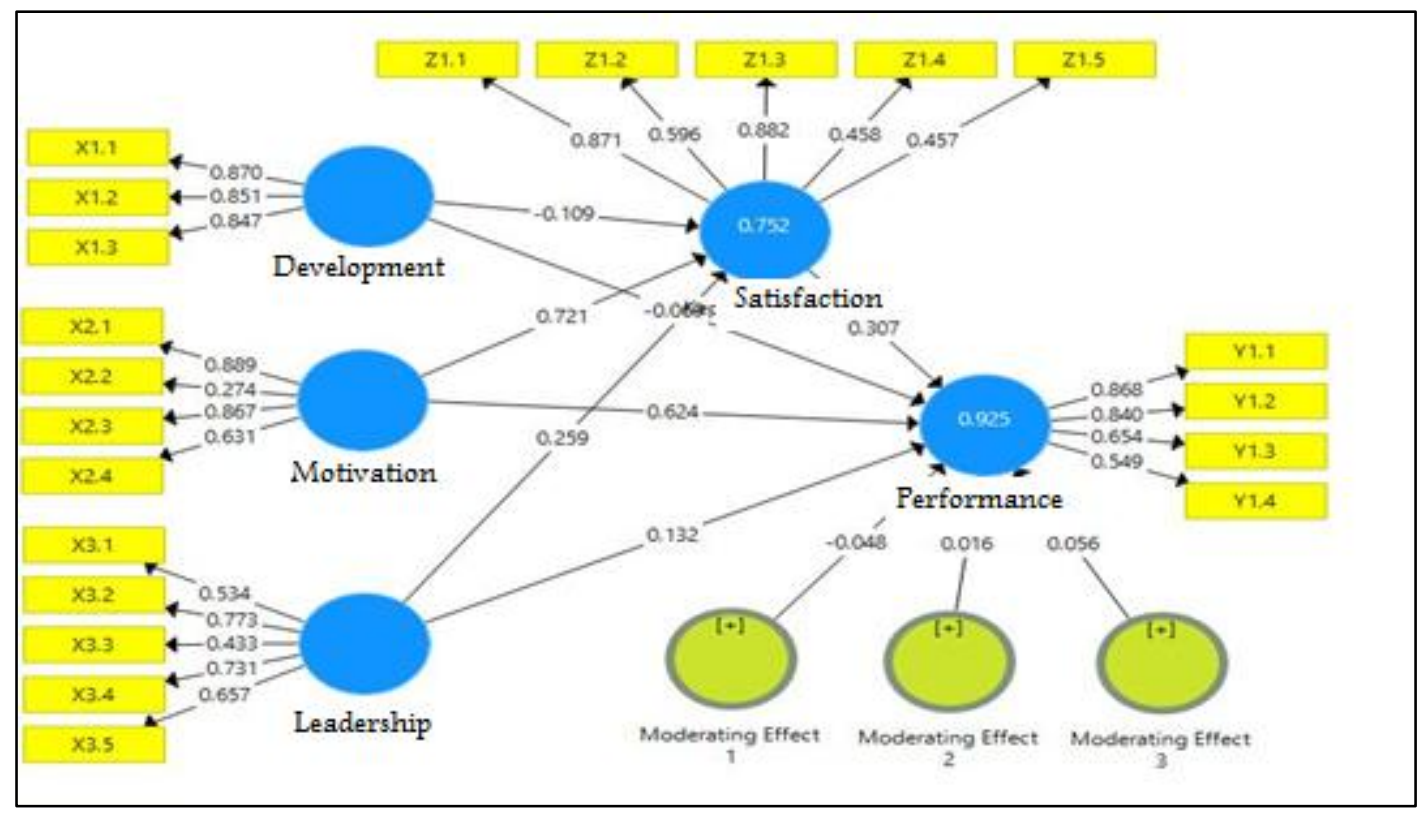

Fig-2: Loading Factor Initial Model

Based on Figure-2, there are indicators with convergent validity value below 0.70 . These indicators, therefore, are excluded from the model: work environment (X2.2), attitude (X2.4), communication methods (X3.1), leadership 
ability (X3.3), positive power (X3.5), attendance (Y3), teamwork skills (Y4), satisfaction of rewards (Z2), satisfaction with coworkers (Z4), and promotion opportunities (Z5). More details are shown in Figure-3.

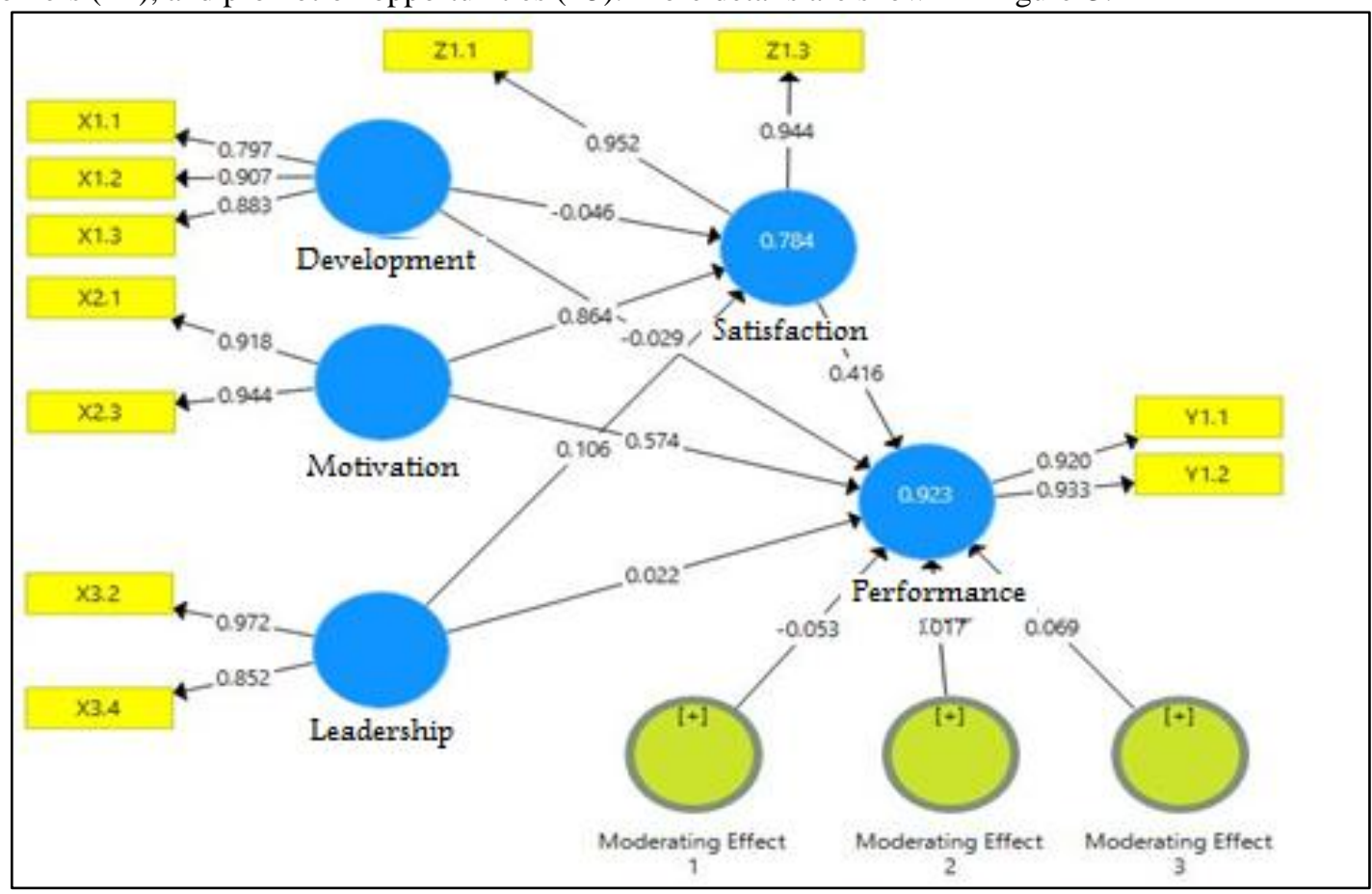

Fig-3: Loading Factor Modifiaction Model

Based on Figure-3, it appears that all indicators have factor loading above 0.70 . To conclude, convergent validity conditions are satisfied.

Discriminant validity: AVE (Average Variance Extracted)

Variable is valid if AVE value > 0.5. The AVE value of each variable in the model is given in Table-2:

Table-2: AVE (Average Variance Extracted)

\begin{tabular}{|l|l|}
\hline Variables & Average Variance Extracted $(\boldsymbol{A V E})$ \\
\hline Leadership & 0,836 \\
\hline Job Satisfaction & 0,898 \\
\hline Performance of Civil Servants & 0,859 \\
\hline Motivation & 0,867 \\
\hline Development & 0,746 \\
\hline
\end{tabular}

As shown in Table-6, the AVE value of all variables is higher than 0.50. To conclude, all variables achieved discriminant validity.

\section{Composite Reliability Test and Cronbach's Alpha Test}

A variable is reliable if its composite reliability value $>0.8$ and Cronbach's alpha value $>0.6$. Composite reliability value and Cronbach's alpha value for each variable in the model are shown in Table-3.

Table-3: Composite Reliability Value

\begin{tabular}{|l|l|l|}
\hline Variables & Composite Reliability & Cronbach's Alpha \\
\hline Leadership & 0,910 & 0,828 \\
\hline Job Satisfaction & 0,947 & 0,887 \\
\hline Performance of Civil Servants & 0,924 & 0,836 \\
\hline Motivation & 0,929 & 0,848 \\
\hline Development & 0,898 & 0,829 \\
\hline
\end{tabular}

Based on Table-3, all variables have composite reliability value $>0.8$ and Cronbach's alpha $>0.6$. Thus, all variables have higher reliability. 


\section{Structural Model Testing (Inner Model) \\ R-squared value}

$\mathrm{R}$-squared $\left(\mathrm{R}^{2}\right)$ is a statistical measure that indicates of how much the influence of independent variables (development, motivation, leadership) has on the dependent variable (performance of civil servants).

Table-4: $\mathbf{R}$-squared $\left(\mathbf{R}^{2}\right)$ value

\begin{tabular}{|l|l|}
\hline Variables & R-Squared \\
\hline Job Satisfaction & 0,784 \\
\hline Performance of Civil Servants & 0,923 \\
\hline
\end{tabular}

As shown in Table-4, the job satisfaction model has an R-squared value of 0.784 and the performance of civil servants model has an R-squared value of 0.923 . It indicates that both models are good models.

\section{Results of Bootstrapping}

The results with the Bootstrapping method are shown as follows:

Table-5: Path Coefficients

\begin{tabular}{|l|l|l|l|l|l|}
\hline & $\begin{array}{l}\text { Original } \\
\text { Sample (O) }\end{array}$ & $\begin{array}{l}\text { Sample } \\
\text { Mean (M) }\end{array}$ & $\begin{array}{l}\text { Standard Deviation } \\
\text { (STDEV) }\end{array}$ & $\begin{array}{l}\text { T Statistics } \\
(|\mathrm{O} / \mathrm{STDEV}|)\end{array}$ & $\begin{array}{l}\text { P } \\
\text { Values }\end{array}$ \\
\hline Leadership -> Job Satisfaction & 0,106 & 0,094 & 0,049 & 2,144 & 0,033 \\
\hline $\begin{array}{l}\text { Job Satisfaction -> Performance of } \\
\text { Civil Servants }\end{array}$ & 0,416 & 0,412 & 0,040 & 10,347 & 0,000 \\
\hline $\begin{array}{l}\text { Moderating Effect 1 -> Performance of } \\
\text { Civil Servants }\end{array}$ & $-0,053$ & $-0,055$ & 0,026 & 2,001 & 0,047 \\
\hline $\begin{array}{l}\text { Moderating Effect 2 -> Performance of } \\
\text { Civil Servants }\end{array}$ & 0,017 & 0,017 & 0,018 & 0,971 & 0,333 \\
\hline $\begin{array}{l}\text { Moderating Effect 3 -> Performance of } \\
\text { Civil Servants }\end{array}$ & 0,069 & 0,071 & 0,031 & 2,201 & 0,029 \\
\hline Motivation -> Job Satisfaction & 0,864 & 0,866 & 0,016 & 53,857 & 0,000 \\
\hline Development -> Job Satisfaction & $-0,046$ & $-0,035$ & 0,051 & 0,910 & 0,364 \\
\hline
\end{tabular}
follows:

Based on the results of the $t$ test and $p$ value as shown in Table 5, the hypothesis test results are given as

Table-6: Hypothesis Test

\begin{tabular}{|l|l|l|}
\hline Hypothesis & Construct & Conclusion \\
\hline 1 & Development -> Job Satisfaction & Hypothesis 1 is rejected \\
\hline 2 & Motivation -> Job Satisfaction & Hypothesis 2 is accepted \\
\hline 3 & Leadership -> Job Satisfaction & Hypothesis 3 is accepted \\
\hline 4 & Moderating Effect 1 -> Performance of Civil Servants & Hypothesis 4 is accepted \\
\hline 5 & Moderating Effect 2 -> Performance of Civil Servants & Hypothesis 5 is rejected \\
\hline 6 & Moderating Effect 3 -> Performance of Civil Servants & Hypothesis 6 is accepted \\
\hline 7 & Job Satisfaction -> Performance of Civil Servants & Hypothesis 7 is accepted \\
\hline
\end{tabular}

Table-6 summarizes the results of the hypothesis testing:

a. Development on job satisfaction obtained $p$ value of $0.364>0.05$ and $t$ statistic of $0.910<t$ value of table of 1.96 , the hypothesis is rejected

b. Motivation on job satisfaction obtained $p$ value of $0.000<0.05$ and $t$ statistic of $53.857>t$ value of table of 1.96 , the hypothesis is accepted

c. Leadership on job satisfaction obtained $p$ value of $0.033<0.05$ and $t$ statistic of $2.144>t$ value of table of 1.96 , the hypothesis is accepted

d. Moderating effect 1 on performance of civil servants obtained $p$ value of $0.047<0.05$ and $t$ statistic of $2.001>t$ value of table of 1.96, the hypothesis is accepted

e. Moderating effect 2 on performance of civil servants obtained $p$ value of $0.333>0.05$ and $t$ statistic of $0.971<t$ value of table of 1.96 , the hypothesis is rejected

f. Moderating effect 3 on performance of civil servants obtained $p$ value of $0.029<0.05$ and $t$ statistic of $2.201>t$ value of table of 1.96, the hypothesis is accepted 
g. Job satisfaction on performance of civil servants obtained $p$ value of $0.000<0.05$ and $t$ statistic of $10.347>t$ value of table of 1.96, the hypothesis is accepted

\section{ANALYSIS RESULTS}

Influence of Development on Job Satisfaction of Civil Servants in the Jambi Regional Police

Development is insignificant on job satisfaction. The results of this study contradict Dessler's [24] theory which suggests that development provides actual benefits for employees in the form of job satisfaction. The findings of this study, however, support the research by Ceylan and Rich [25] which found that development did not influence job satisfaction.

Development which consists of education, work experience and training cannot improve job satisfaction of the civil servants in the Jambi Regional Police. This is due to the type of work done by these civil servants has no correlation with education, work experience, and training they received so far.

\section{Influence of Motivation on Job Satisfaction of Civil Servants in the Jambi Regional Police}

Motivation has a positive significant impact to job satisfaction. The more optimal the motivation given is, the greater the job satisfaction of the civil servants in the Jambi Regional Police will be.

Motivation consists of supervision, work environment, rewards and attitude. These indicators become a measure of motivation among civil servants of the Jambi Regional Police. Direct supervision of the leader, comfortable work space/environment, complete infrastructure in workplace, and the provision of performance allowances, meal allowances, overtime pay, as well as moral support from co-workers have a positive impact on job satisfaction of the civil servants in the Jambi Regional Police. The results of this study are in line with research by Ahmed et al., [26], Brahmasari [27], Ernawati [28], Job \& Rafif [29], Maharjan [30], Saleem et al., [31] and Shah et al., [32].

\section{Influence of Leadership on Job Satisfaction of Civil Servants in the Jambi Regional Police}

Leadership has a positive significant effect on job satisfaction. The results of this study are in line with the research of Andri et al., [33], Bushra Fatima et al., [34], Nursiah [35], Rehman et al., [36], and Sasongko [37].

Leadership consists of five indicators: communication methods, driving motivation, leadership ability, decision making, and positive power. It means that the better the leadership skills owned by the leader are, the greater the job satisfaction of civil servants in the Jambi Regional Police is. Leaders, who are able to communicate well, provide motivations, and exercise positive power, can create job satisfaction among civil servants in the Jambi Regional Police.

\section{Influence of Development on Performance of Civil Servants in the Jambi Regional Police with Job Satisfaction as Moderator Variable}

Development has a positive significant impact to performance of civil servants in the Jambi Regional Police with job satisfaction as the moderator variable. As such, the results of this study are in line with the research of Adeloka [38] which found a significant relationship between development and performance of civil servants, thus, affecting job satisfaction.

Job satisfaction directly influences performance of the civil servants by involving development. This shows that indicators of development: education, work experience and training are able to increase job satisfaction of civil servants in the Jambi Regional Police and must be accompanied by an improvement of the civil servants performance, in accordance with the vision and mission of the institution. In order to improve the performance of the employees, they need to develop themselves, for instance, by gaining new knowledge and improving skills. By exercising those efforts, leaders can improve job satisfaction of employees at work.

\section{Influence of Motivation on Performance of Civil Servants in the Jambi Regional Police with Job Satisfaction as Moderator Variable}

Motivation which is moderated by job satisfaction has insignificant effect on the performance of civil servants in the Jambi Regional Police. Observations and data test results show that most of the civil servants in the Jambi Regional Police tend to be neutral in dealing with various matters relating to job satisfaction.

Insignificant influence of job satisfaction moderating motivation and performance of civil servants is caused by various factors and other variables. Job satisfaction as the moderator variable should be either treated as purely independent variable or replaced with other variable as the moderator.

The results of this study establish the findings of Selvanathan et al., [39] which concluded that to get the most effective motivation to work in order to improve employee performance is to have a friendly work environment and 
provide training for employees. Tanuwibowo and Setiawan [40] in their research also showed that the level of motivation of employees can affect their performance.

\section{Influence of Leadership on Performance of Civil Servants in the Jambi Regional Police with Job Satisfaction as Moderator Variable}

Leadership has a significant effect on performance of civil servants in the Jambi Regional Police with job satisfaction as the moderator variable. In this sense, job satisfaction has the effect of strengthening the influence of leadership on the performance of the civil servants. The results of this study are in line with research by Charles et al., [41] and Palupi [10].

\section{Influence of Job Satisfaction on Performance of Civil Servants in the Jambi Regional Police}

Job satisfaction has a significant effect on performance of civil servants in the Jambi Regional Police. The higher the job satisfaction of employee is, the employee performance increases. Employees who are satisfied with the results of their work, coworkers, supervision, and the rewards received show good performance. In addition, duties appropriate to the employee's position at work and on-time and good payment of salary can improve employee performance. The results of this study support the research by Aruna \& Prasanga [42], Dizgah et al., [43], Funmilola et al., [44], Gibson et al., [45], Perera et al., [46], Pushpakumari [47], and Suwedana [48].

\section{CONCLUSiOnS}

There is no influence of development on job satisfaction of civil servants in the Jambi Regional Police due to the duties and functions of the civil servants having no correlation with the education, work experience, and training received by them so far.

Motivation has a positive effect on job satisfaction. Direct supervision from the leader at work, comfortable workspace, complete infrastructure, receiving performance allowances, meal allowances, overtime pay and moral support from coworkers have a positive impact to job satisfaction of civil servants in the Jambi Regional Police.

Leadership has a positive significant effect on job satisfaction. It has 5 indicators: communication methods, driving motivation, leadership ability, decision making, and positive power. These five indicators serve as a measure of leadership variable in the Jambi Regional Police.

Job satisfaction has an influence on employee performance. Greater job satisfaction of the employee will result in the improvement of the employee performance. In this sense, job satisfaction can be explained by its indicators: satisfaction with tasks, satisfaction of rewards, satisfaction of supervision, and satisfaction with coworkers.

Employee development affects the performance of civil servants in the Jambi Regional Police with job satisfaction as the moderator variable. Job satisfaction directly affects the performance of the civil servants by involving development. On the other hand, motivation moderated by job satisfaction has insignificant impact to performance of the civil servants, meaning that it cannot improve the employee performance. Furthermore, job satisfaction can moderate the influence of leadership on the performance of civil servants in the Jambi Regional Police.

\section{RECOMMENDATIONS}

Recommendations offered and presented by the author are:

a. For the Chief of the Jambi Regional Police

Encouragement for civil servants to continue their study at formal educational institution and providing training in accordance with their fields of work are recommended to increase job satisfaction level of the civil servants.

b. For the Head of Human Resources Bureau

Improvement in employee development, motivation, leadership, performance of civil servants, and job satisfaction both for the heads of work unit and staffs are expected to carry out. These efforts can improve job satisfaction and employee performance.

c. For the Heads of the Work Unit

The heads of the work unit are expected to motivate their subordinates to work so that the employees will obtain good results at their work.

d. For Other Researchers

More studies on employee development are suggested by the author for other researchers because the results of this study found that employee development variable cannot improve employee performance. 


\section{REFERENCES}

1. Shafiq, S., \& Hamza, S. M. (2017). The effect of training and development on employee performance in private company, Malaysia. International Journal of Education, Learning and Training, 2(2), 7-12.

2. Kapahang, F. F., Rorong, A. J., \& Tampi, G. B. (2015). Pengaruh Motivasi Terhadap Kinerja Pegawai (Studi Pada Kantor Kecamatan Ratahan Kabupaten Minahasa Tenggara). Jurnal Administrasi Publik, 3(31).

3. Ehling, P., \& Haushalter, D. (2014). When does cash matter? Evidence for private firms.

4. Akhmal, R., Mardhiana, R., \& Msayar, H. (2018). Parental sacrifice as perceived by adolescents among economics foundation students in iium. International E-Journal of Advances in Social Sciences, 4(10), 178-184.

5. Omollo, P. A. (2015). Effect of motivation on employee performance of commercial banks in Kenya: A case study of Kenya Commercial Bank in Migori County. International Journal of Human Resource Studies, 5(2).

6. Sadad, A. (2011). Pengaruh Pemotivasian Terhadap Efektivitas Kerja Pegawai di Dinas Pendidikan Provinsi Riau. Jurnal Kebijakan Publik, 2(2).

7. Robbins, S. P., \& Timothy A. J. (2013). Organizational Behaviour. 15th. Prentice Hall., New Jersey.

8. Juniari, N. K. E., Riana, I. G., \& Subudi, M. (2015). Pengaruh Motivasi Terhadap Kepuasan Kerja dan Kinerja Pegawai Negeri Sipil (PNS) di Sekolah Tinggi Pariwisata Nusa Dua Bali. E-Jurnal Ekonomi dan Bisnis Universitas Udayana.

9. Madanchian, M., Hussein, N., Noordin, F., \& Taherdoost, H. (2016). Effects of leadership on organizational performance. Economics and Education.

10. Palupi, D. A. P., Cahjono, M. P., \& Satyawati, E. (2017). Effect of leadership on the job satisfaction with organizational commitment and trust in leader as mediators. Review of Integrative Business and Economics Research, 6(4), 400.

11. Sedarmayanti. (2016). Manajemen Sumber Daya Manusia. Reformasi Birokrasi dan Manajemen Pegawai Negeri Sipil. PT Refika Aditama, Bandung.

12. Voon, M. L., Lo, M. C., Ngui, K. S., \& ve Ayob, N. B. (2011). The İnfluence of Leadership Styles on Employees' Job Satisfaction in Public Sector Organizations in Malaysia. International Journal of Business, Management and Social Sciences, 2(1):24-32.

13. Umiarso. (2012). Pendidikan Kepemimpinan Islam Antara Teori Dan Praktik. Jogjakarta: Ar-Ruzz Media.

14. Siagian, S. P. (2012). Teori Motivasi dan Aplikasinya. Jakarta: Bina Aksara.

15. Thoha, M. (2010). Perilaku Organisasi: Konsep Dasar dan Aplikasinya. Jakarta: Raja Grafindo Persada.

16. Sunyoto, D. (2013). Manajemen Sumber Daya Manusia. Jakarta: Center for Academic Publishing Service.

17. Susanto, A., Sari, C. A., \& Rachmawanto, E. H. (2017, August). Hybrid method using HWT-DCT for image watermarking. In 2017 5th International Conference on Cyber and IT Service Management (CITSM) (pp. 1-5). IEEE.

18. Rahman, A., \& Gunawan, H. (2017). Pengaruh Motivasi, Kepuasan Kerja, Dan Pengembangan Karir Terhadap Kinerja Pegawai Bagian Perlengkapan Sekretariat Daerah Kota Makassar. Jurnal Mirai Management, 2(2).

19. Timpe, A. D. (2014). Memimpin Manusia, Seri Ilmu dan Seni Manajemen Bisnis. Jakarta: PT Gramedia Asri Media.

20. Mathis, D., \& Shoelson, S. E. (2011). Immunometabolism: an emerging frontier. Nature Reviews Immunology, 11(2), 81.

21. Priyono, F., \& Medistya, A. (2012). Pengaruh Gaya Kepemimpinan Terhadap Kepuasan Kerja Dan Komitmen Manajemen Pada Laboratorium Mawar. Journal of Business and Banking, 2(1).

22. Rivai, V., \& Sagala, E. J. (2014). Manajemen Sumber Daya Manusia Untuk Perusahaan. Jakarta: Rajagrafindo Persada, Jakarta.

23. Suprapta, M., Sintaasih, D. K., \& Riana, I. G. (2015). Pengaruh kepemimpinan terhadap kepuasan kerja dan kinerja karyawan (studi pada Wake Bali Art Market Kuta-Bali). E-Jurnal Ekonomi dan Bisnis Universitas Udayana.

24. Dessler, G. (2011). Manajemen Sumber Daya Manusia. Jakarta: Penerbit Indeks.

25. Ceylan, S., \& Topçu, Y. (2014). Pyrolysis kinetics of hazelnut husk using thermogravimetric analysis. Bioresource technology, 156, 182-188.

26. Ahmed, I. (Ed.). (2010). The plight of the stateless Rohingyas: Responses of the state, society \& the international community. University Press.

27. Brahmasari, I. A., \& Suprayetno, A. (2008). Pengaruh motivasi kerja, kepemimpinan dan budaya organisasi terhadap kepuasan kerja karyawan serta dampaknya pada kinerja perusahaan (Studi kasus pada PT. Pei Hai International Wiratama Indonesia). Jurnal Manajemen dan kewirausahaan, 10(2), 124-135.

28. Ernawati, K., Soesilo, B., \& Duarsa, A. (2010). Rifqatussa'adah. Hubungan faktor risiko individu dan lingkungan rumah dengan malaria di Punduh Pedada Kabupaten Pesawaran Provinsi Lampung Indonesia, 51-57.

29. Ayub, N., \& Rafif, S. (2011). The relationship between work motivation and job satisfaction. Pakistan Business Review, 13(2), 332-347. 
30. Maharjan, A., Bauer, S., \& Knerr, B. (2012). Do rural women who stay behind benefit from male out-migration? A case study in the hills of Nepal. Gender, Technology and Development, 16(1), 95-123.

31. Saleem, M. Y., Mirza, J. I., \& Haq, M. A. (2010). Combining ability analysis of some morphophysiological traits in Basmati rice. Pakistan Journal of Botany, 42(5), 3113-3123.

32. Shah, M. P., Bchir, O. J., \& Movva, S. (2012). U.S. Patent Application No. 13/220,733.

33. Supriatna, A. (2011). The Feasibility Study of Land Readjustment for Kampung Upgrading in Jakarta. University of Twente Faculty of Geo-Information and Earth Observation (ITC).

34. Bushra, F., Ahmad, U., \& Naveed, A. (2011). Effect of transformational leadership on employees' job satisfaction and organizational commitment in banking sector of Lahore (Pakistan). International journal of Business and Social science, 2(18).

35. Nursiah, A. (2004). Teknik membaca dalam pelajaran Bahasa Indonesia pada siswa SD. Karya Tulis Ilmiah, Watampone.

36. Rehman, H. U., Aziz, T., Farooq, M., Wakeel, A., \& Rengel, Z. (2012). Zinc nutrition in rice production systems: a review. Plant and soil, 361(1-2), 203-226.

37. Sasongko, J., Rohr, C., \& Tjondronegoro, D. (2008, October). Efficient generation of pleasant video summaries. In Proceedings of the 2nd ACM TRECVid Video Summarization Workshop (pp. 119-123).

38. Adekola, O., \& Mitchell, G. (2011). The Niger Delta wetlands: threats to ecosystem services, their importance to dependent communities and possible management measures. International Journal of Biodiversity Science, Ecosystem Services \& Management, 7(1), 50-68.

39. Selvanathan, E. A., Selvanathan, S., \& Keller, G. (2016). Business Statistics: Australia New Zealand with Student Resource Access for 12 Months. Cengage AU.

40. Setiawan, E., Wilson, A. A., Mizrahi, R., Rusjan, P. M., Miler, L., Rajkowska, G., ... \& Meyer, J. H. (2015). Role of translocator protein density, a marker of neuroinflammation, in the brain during major depressive episodes. JAMA psychiatry, 72(3), 268-275.

41. Fried, C. (2015). Contract as promise: A theory of contractual obligation. Oxford University Press, USA.

42. Prasanga, A. A., \& Gamage, A. S. (2012). Job Satisfaction and Job Performance of the Sailors in Rapid Action BoatSquadron of Sri Lanka Navy. Sri Lankan Journal of Human Resource Management, 3(1).

43. Dizgah, M. R., Chegini, M. G., \& Bisokhan, R. (2012). Relationship between job satisfaction and employee job performance in Guilan public sector. Journal of Basic and Applied Scientific Research, 2(2), 1735-1741.

44. Funmilola, O. F., Sola, K. T., \& Olusola, A. G. (2013). Impact of job satisfaction dimensions on job performance in a small and medium enterprise in Ibadan, South Western, Nigeria. Interdisciplinary journal of contemporary research in business, 4(11), 509-521.

45. Gibson, S. I. (2000). Plant sugar-response pathways. Part of a complex regulatory web. Plant Physiology, 124(4), 1532-1539.

46. Perera, C., Liu, C. H., Jayawardena, S., \& Chen, M. (2014). A survey on internet of things from industrial market perspective. IEEE Access, 2, 1660-1679.

47. Pushpakumari, M. G. K. (2009). Performance of Lower Grades of Natural Rubber in Tyre Tread Compounds (Doctoral dissertation, University of Sri Jayewardenepura, Nugegoda).

48. Suwedana, S., Natajaya, N., \& Sunu, I. A. (2013). Kontribusi Kepemimpinan Kepala Sekolah, Motivasi Berprestasi, Dan Kepuasan Kerja Terhadap Kinerja Guru (Studi Tentang Persepsi Para Guru Smk Negeri 1 Bangli). Jurnal Administrasi Pendidikan UNDIKSHA, 4(1), 74860. 